\title{
Land Use and Land Cover Change in the Coastal Area of Watamu Mida Creek, Kenya
}

\author{
Fikir Alemayehu \\ Department of Land Resource Management and Agricultural Technology, University of Nairobi, Nairobi, Kenya \\ Email: fikiral2@gmail.com
}

Received 19 April 2016; accepted 26 June 2016; published 29 June 2016

Copyright (C) 2016 by author and Scientific Research Publishing Inc. This work is licensed under the Creative Commons Attribution International License (CC BY). http://creativecommons.org/licenses/by/4.0/

c) (i) Open Access

\section{Abstract}

Watamu Mida creek coastal areas, mainly the shoreline, the mangroves and the general environment have been changing due to the impact of land use change, shoreline erosion, human population pressure and the expansion of tourism sector. This research assesses the impact of land use change on mangrove dynamics and shoreline erosion as well as the main driving factors that cause these changes in Watamu Midacreek. This study uses old aerial photographs (1969 and 1989), current high resolution satellite images World view (2010) and ground truthing in combination with information from the local community to analyze the impact of change in land use from 19692010. Land use and cover types were visually interpreted, digitized and delineated using aerial photographs of 1969, 1989 and 2010 satellite images in ArcGIS.9.3.1 and ERDAS IMAGINE 2014 software. The results of the land use change between 1969 and 1989 showed a decline of scrub land, miscellaneous coastal vegetation, coastal bush, thicket with trees and mangroves, whereas new types of land use which emerged during this period were town and barren land. The greatest land use change rate observed between 1969 and 1989 was in miscellaneous coastal vegetation at $2.5 \%$, while coastal bush experienced a significant negative change rate of $-6.5 \%$. The main land use changes observed between 1989 and 2010 were increasing coastal bush, an expansion of town and urban areas, hotels and private holiday houses. Encroachments into the mangrove forest have been observed both by local people and foreign private holiday house owners. The change in land use had an impact on shoreline changes as well. Areas mainly covered by old trees, and coastal bushes which protected the shoreline from erosion currently have been converted into very big hotels and several private holiday house complexes. The main drivers of land use change were human population growth and policy (through weakness of law enforcement). Policies and regulations which are not currently implemented need to be updated based on the current pressurestate situation, and there should be strong law enforcement and strict regulation to control any unplanned developments along the coast and in the neighboring hinterland. 


\section{Keywords}

\section{Watamu Mida Creek, Coastal Area, Land Use Change, Shoreline, Mangroves, Policies}

\section{Introduction}

Land use is the way human beings make use of the land and its resources. Land use refers to the uses of land for various purposes, such as wildlife habitat, forest agriculture, and settlements (Ahmed, 2011). Ever since the beginning of agriculture, the human population and the consumption of resources have increased steadily throughout the world (Ricardo et al., 2003). These result in the conversion of forest and natural areas into agricultural land, pastureland and settlement areas. Over the next century, land-use and land-cover changes are likely to become one of the most significant challenges facing the Earth (Gutman et al., 2004). Hansen et al. (2004) in his study pointed out that the expansion and intensification of human land use in recent decades are resulting in major changes in biodiversity. As stated by Turner et al. (1995), historical land use and land cover change has happened predominantly in response to population growth, technological advances and economic opportunity. This shows that human beings and their activities take the biggest portion of responsibilities in the conversion or modification of the natural environment. This is due to the fact that the growing human population demand cannot be satisfied without alteration or conversion in land use and land cover. Agarwal et al. (2000) indicated that on a global scale nearly 1.2 million $\mathrm{km}^{2}$ of forest and woodland and 5.6 million $\mathrm{km}^{2}$ of grass land and pasture have been converted to other uses during the last three centuries. A parallel study by Munasinghe and Shearer (1995) indicates that human induced land use change, such as land clearing, agricultural intensification, and urbanization, is currently the most significant factor of global change and its effects are already with us. However, land use change is also the backbone of economic development and supports the livelihood of billions of people by providing most of their economic and social benefits (Wu, 2008). Therefore, understanding the impact of land use change is crucial to take informed decisions to improve the management of natural resources. The main focus of this research is to quantify the land use cover change in Watamu Mida creek coastal area in the period 1969-2010 and identify the drivers of the changes in mangrove and shoreline erosion.

\section{Materials and Methods}

\subsection{The Study Area}

The study was conducted in Watamu Mida creek, in Coast Province, Kilifi County, Kenya (Figure 1). The study area covered approximately 60 square kilometers. Mida creek is a biologically important and complex tidal marine multi-habitat ecosystem supporting the adjacent local communities by providing foods, building materials and tourism revenues (Weru et al., 2000). The Creek expands across an area of 32 square kilometers. According to the population census of 2009 , the population of the study area was 101,689 with estimated growth rate of $3.05 \%(G O K, 2009)$.

The coastal climate of Kenya is influenced mainly by large-scale pressure systems of the Western Indian Ocean and monsoon winds. Rainfall occurs during two distinct periods; the long rains between March and May and the short rains usually between October and December with mean annual rainfall that ranges from 500 - 900 $\mathrm{mm}(\mathrm{GOK}, 2009)$. The rainfall pattern around Mida creek and Watamu areas is bimodal where the long rains occur in April to June with a peak in May (Gang and Agatsiva, 1992) (Figure 2 and Figure 3).

Generally, land use in the coastal region falls into four main categories: livestock ranches in the hinterland, agricultural settlement schemes, private land along the immediate coastline, and un-delineated government land (GOK, 2009). Agriculture is one of the main land use types with tree crops such as; cashewnuts, mangoes, and coconuts occupying a large area of Mida creek (Gang and Agatsiva, 1992).

\subsection{Data Compilation for Land Use Change Analysis}

The land use data in Watamu Mida creek study area were based on over 40 years' of time series aerial photographs and satellite imagery. To determine change in land use, the information was extracted from the aerial photographs of 1969, 1989 and an orthorectified 2010 World View satellite image (0.5 m resolution). In total 23 
scanned photographs (digital photographs) at 800 dip resolution were acquired from the Survey of Kenya office. The aerial photographs had a scale of 1:60,000 and 1:50,000 for 1969 and1989 respectively.

The orthorectified and mosaic 2010 World View image and Spot image 2003 with $(2.5 \mathrm{~m})$ resolution served as master images for the orthorectification of the older aerial photographs. The Universal Transverse Mercator (UTM) geographic projection WGS84 zone 37 South was used to georeference the 1969 and 1989 aerial photographs and to harmonize the old aerial photographs and the 2010 image. The orthorectification and georeferencing

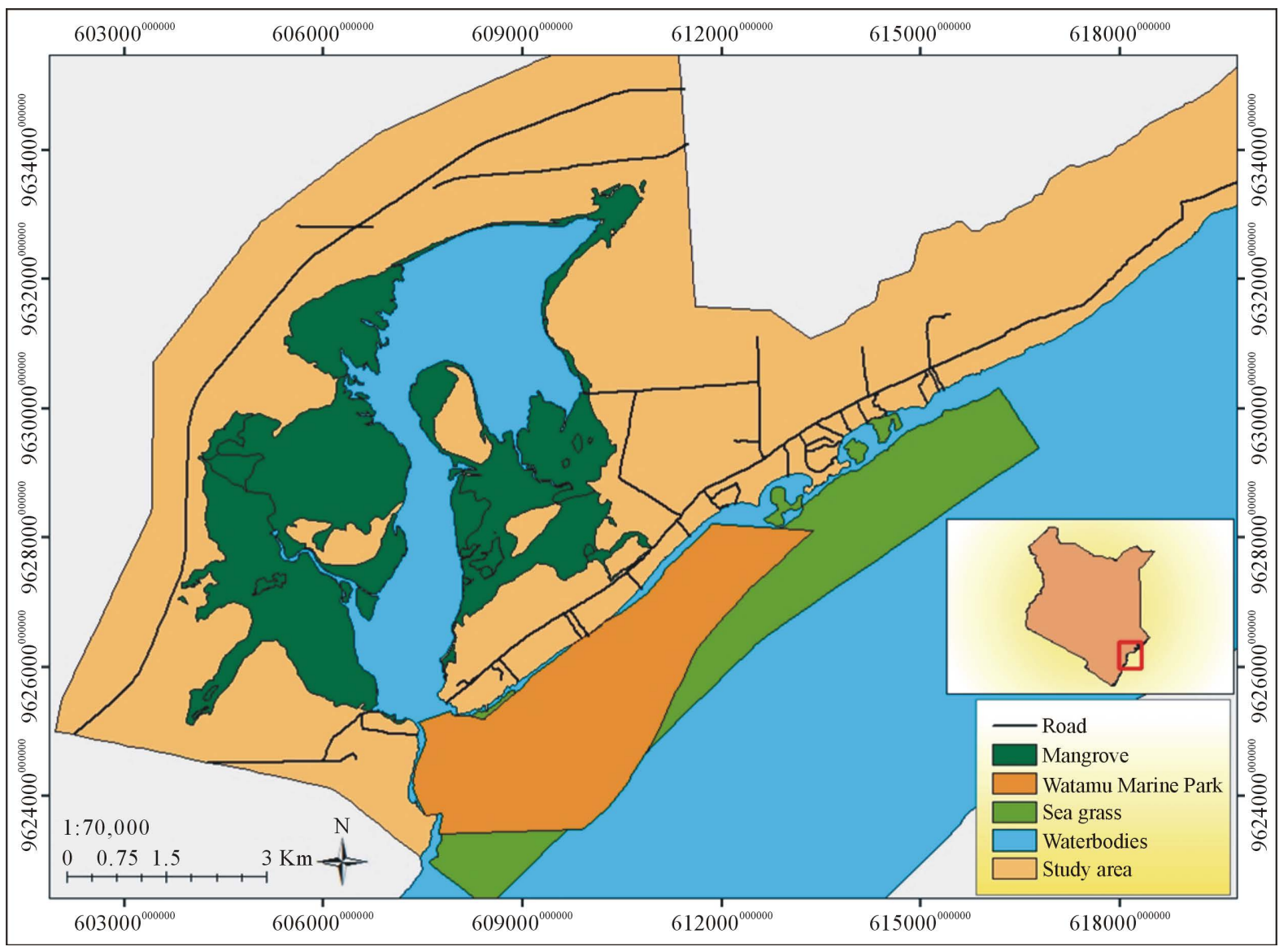

Figure 1. Location map of the study area.

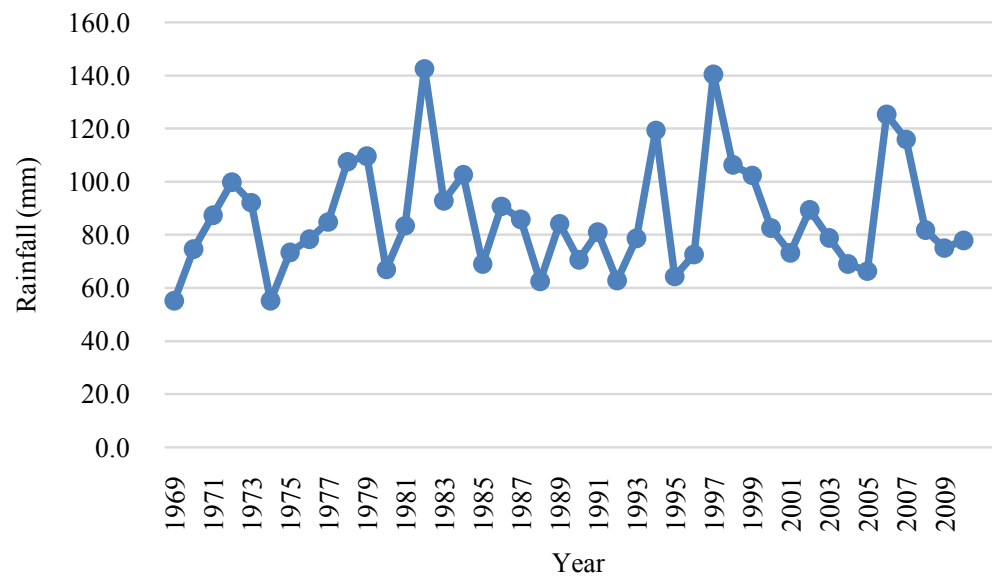

Figure 2. The trend of rainfall distribution in the study area (Source Kenya Metrological Service). 


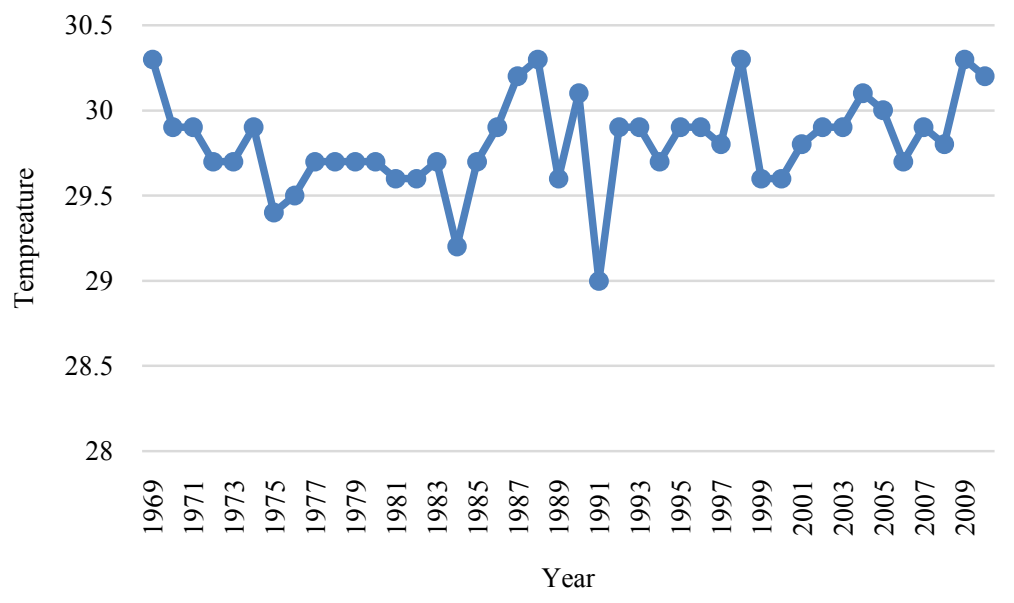

Figure 3. The trend of temperature in the study area (Source Kenya Metrological Service).

was prepared using ERDAS IMAGINE software, 2014 version. Once the aerial photographs were georeferenced and rectified a photo mosaic was prepared for the 1969 and 1989 aerial photographs. Prior to on screen visual interpretation and digitizing to prepare; the land use maps, mangrove cover and shoreline change maps, the aerial photographs and the satellite images was spatially enhanced using radiometric and photography enhancement tools in ERDAS IMAGINE.

\subsection{Land Use Change Data Analysis}

Using the mosaic aerial photographs of 1969 and 1989, training sites were collected on ERDAS EMAGINE using signature editor tools. Once the signatures were collected a supervised classification was performed. However since the old aerial photographs have a single band and low spectral resolution the majority of the classes were misclassified. Hence to improve the land use classification a combined methodology was used. The output of the supervised classification was used as a basis for visual interpretation and classification. In the study of land use and land cover classifications, it is common to use visual interpretation, computerized classification or a combination of the two (Horning, 2004). Land use types were visually digitized and delineated following the; texture, pattern, tone and shape using ArcGIS.9.3.1 software. The land use change for 2010 satellite image was also visually interpreted and digitized on screen. All screen digitization were done at a scale of 1:5000 for uniformity and to provide detail and precision.

After the necessary editing and cleaning of the data in ArcGIS, the preliminary land use map classification for 2010 was verified in the field through cross checking with previously collected GPS points. To improve the accuracy of the land use cover classification over a hundred ground control points were also taken. A simple random sampling method was used to collect the GPS points during the household survey. In addition, several ground level pictures were taken for the 2010 land use map verification. GPS points of; old remnant trees and historical information (e.g. ruins) gathered from households who had lived in the area for over 40 years helped to improve the classifications on the old aerial photographs. The GPS points gathered were overlaid on the classified land use map to check the accuracy. Furthermore, for the 2010 land use classification, the land use map was exported to Google Earth (2012) and overlaid to check its accuracy.

In summary, 13 land use and cover classes were identified for 1969, which were increased to 15 for 1989, and 19 classes for the year 2010. Some of the current land use types are defined in (Table 1) below. The corresponding land use information for 1969 and 1989 were gathered from the respondents during the household survey. Additional literature was also reviewed, and old topographical maps helped to finalize the process of the land use classification.

The land use changes between the three periods were quantified to show land use change conversion for the 41 year period. The change rates of single land use type was quantitatively measured based on Peng et al. (2008) procedures. This index is recognized as one of the most widely used indices for detecting the land use change rates (Peng et al., 2008). 
Table 1. Description of land use and cover classifications.

\begin{tabular}{|c|c|}
\hline Land use type & Land use classifications \\
\hline Miscellaneous coastal vegetation & Coastal vegetation cover dominated by old big indigenous trees \\
\hline Thickets with trees & Mainly coastal bush with big old trees dominant \\
\hline Coastal bush with trees & Dominated by coastal bush with the presence of few old trees \\
\hline Forest & Coastal Forest \\
\hline Settlement with mixed cash crops & $\begin{array}{c}\text { Farm settlements with cash crop trees such as; mango, cashew nuts, coconuts } \\
\text { and other indigenous trees together with seasonal crops such as maize, } \\
\text { and a small number of livestock }\end{array}$ \\
\hline Mangrove forest & All mangrove forest in the study site \\
\hline Residential plots & $\begin{array}{c}\text { Private plots along the beach with residential and holiday } \\
\text { houses and thick vegetation cover }\end{array}$ \\
\hline Seasonal Swamp & Area regularly flooded during rainy season \\
\hline Beach & Areas adjacent to hotels and covered by white sand and used as a recreational area \\
\hline Town & $\begin{array}{l}\text { Areas composed of built-up areas under intensive use with residential, commercial } \\
\text { and business centers and institutional facilities and other infrastructure. }\end{array}$ \\
\hline Barren land & $\begin{array}{c}\text { Land which is not covered by any vegetation at the time of the image acquisition } \\
\text { and field verification (for the current period) }\end{array}$ \\
\hline Settlement & $\begin{array}{c}\text { Mainly houses and villages with little vegetation or tree cover and where } \\
\text { there is expansion of built-up areas (in progress) }\end{array}$ \\
\hline Private holiday houses & Houses constructed for the purposes of rent and tourist accommodation \\
\hline
\end{tabular}

where $K 1$ is land use dynamic degree, measuring the change rate of the target land use type; $U a$ and $U b$ are the area of the target land use type at the beginning and end of the study period respectively; and $T$ is the study period, which is usually measured by units of a year. The index of $K 1$ can concisely express the overall characteristics of the change of a certain land use type in the study period.

\subsection{Socioeconomic Data Collection and Analysis}

In order to better understand the drivers of land use change, shoreline erosion and mangrove dynamics, a socioeconomic assessment was conducted using household questionnaires, Focused Group Discussions and key informant interviews. The information was gathered from local resources users of the study area based on the land use change, shoreline erosion and mangrove change dynamics results which were analysed from the GIS/RS preliminary analysis. The main local resource users in the study area are; fisherman, curio sellers, boat operators, safari sellers, tour guides, diving institutions, beach operators, hoteliers, longtime residents living along the beach, NGOs, community conservation groups and, women groups. The household survey included 60 respondents from different resource users groups and villages. In order to understand and assess the biophysical and human causes of land use cover change there are several approaches and models to link land use cover change with the main driving forces. Some of the most common models used are: Driving forces-Land Change, Driving forces-Actor-Land Change, Driving forces/Actor-Land Change, and Actor-Land Change (Hersperger et al., 2010). Some studies integrate social and biophysical variables to represent drivers of land use change cover while others combine socioeconomic household data and remote sensing data to understand the process of land use change (Roeder and Joachim, 2009; Fox, 2003). The current study used Driving Forces- Land Change model with one dependent variable (the spatial analysis of land use change) and several independent variables (population data, rainfall data and policies) in combination with qualitative data drawn from; a household survey, Focused Group Discussion and Key Informant interviews, to gather historical information related with changes in 
mangroves, land use and the shoreline. The data were analyzed using a multiple regression model. Qualitative data gathered from key informant interviews at household level can help to better understand and answer some of the information gaps that emerge during classification (National Research Council, 2005). Moreover, the approach used in the study clarified and improved on the land use cover classification of the 1969 and 1989 aerial photo mosaics through the use of GPS points. Data captured at each household were used to garner further information about the household and their use of the land, including identifying remnants vegetation cover, for example identifying old trees as a reference to cross check the earlier classification.

\section{Results and Discussion}

\subsection{Land Use Change from 1969-2010}

The land use cover types in the study area were categorized into six main classes' namely coastal vegetation (bush, scrub, and thickets), mangrove and coastal forest, farmland with settlements, residential houses, and sea water bodies, sandy beach, tide flats and mudflats. The mangrove forest is a source of livelihood and ecotourism activities for the surrounding communities while, the beach, and forest, serve as a main touristic recreational area. There are two boardwalks within the mangrove forest run by the community as part of ecotourism activities which support the locals. For the year 1969, 13 land use types were classified while, for 198915 were classified, and in 2010, 19 land uses were identified. The total area of land use mapped for 1969, 1989 and 2010 was 11,207.9 ha, 11,181.3 ha, and 11,235.7 ha respectively (Figures 4-6). The slight variations on the total area of the study were due to the variability and coverage of the aerial photographs and satellite image for each year.

The result of the land use change as displayed in (Table 2) shows conversion of land from one use to another, as well as the emergence of new land use types from 1969-2010. In 1969 settlements with mixed cash crop (2358.6 ha) were the main land use in the area followed by mangroves (2072.2 ha), thickets with trees ( 889.1 ha) and forest $(855.6 \mathrm{ha})$ with the sea water accounting for $33.5 \%$ of the total area. The land use change analysis (comparison between 1969 and 1989) show a decline in most of vegetation covers including mangrove forest and emergence of new land use in 1989. As mangrove forest decreased by $3 \%$, there was emergence of urban

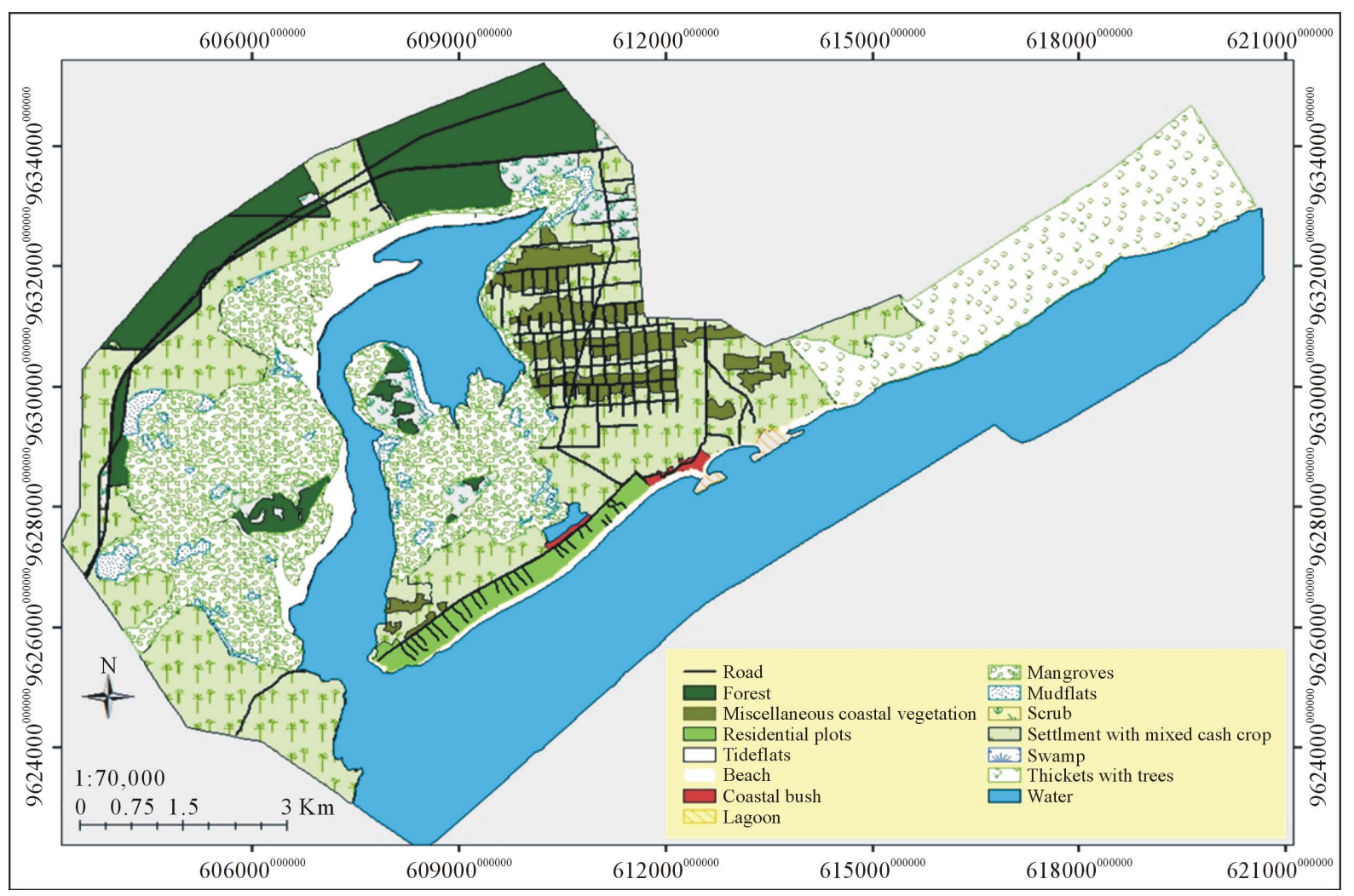

Figure 4. Land use and cover map of the study area in 1969. 


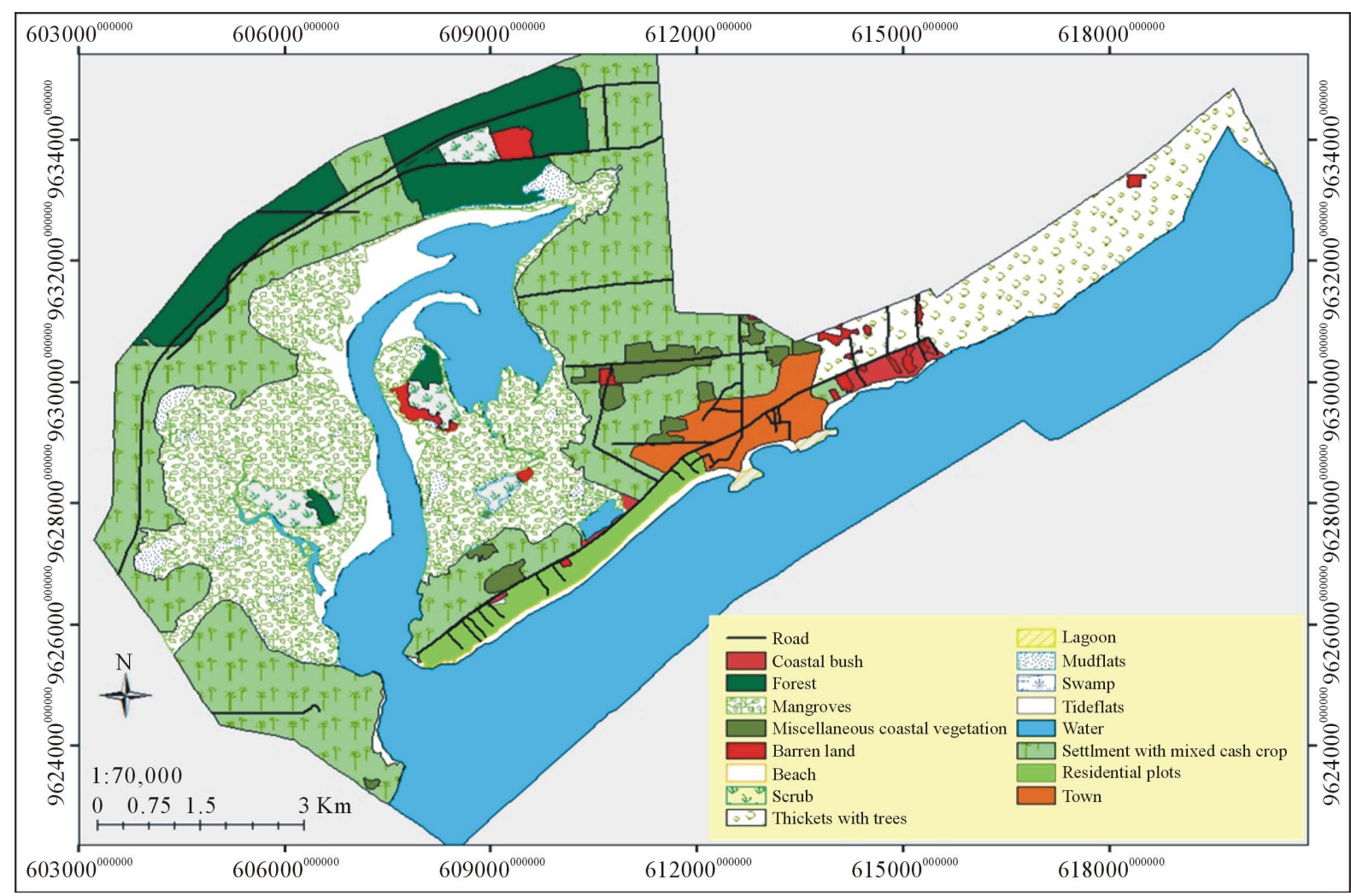

Figure 5. Land use and cover map of the study area in 1989.

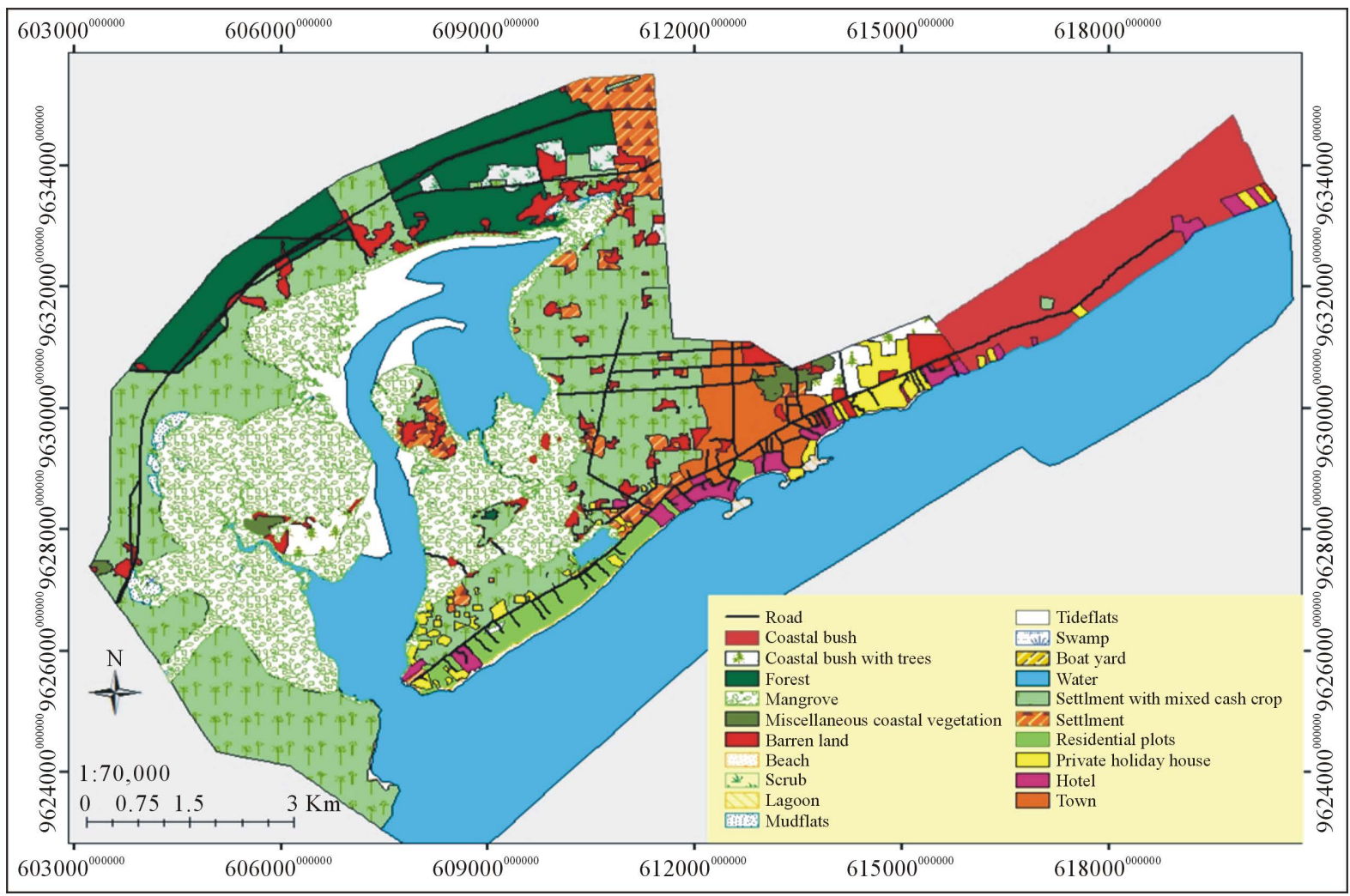

Figure 6. Land use and cover map of the study area in 2010. 
Table 2. Land use and cover area from 1969-2010.

\begin{tabular}{|c|c|c|c|c|c|c|c|c|}
\hline \multirow{2}{*}{ Land use and cover type } & \multirow{2}{*}{1969 (ha) } & \multirow{2}{*}{$(\%)$} & \multirow{2}{*}{1989 (ha) } & \multirow{2}{*}{$(\%)$} & \multirow{2}{*}{2010 (ha) } & \multirow{2}{*}{$(\%)$} & \multicolumn{2}{|c|}{ Change computation $(\%)$} \\
\hline & & & & & & & 1969-1989 & $1989-2010$ \\
\hline Scrub & 213.6 & 1.9 & 154.1 & 1.37 & 69.8 & 0.62 & 1.4 & 2.6 \\
\hline Miscellaneous coastal vegetation & 325.7 & 2.9 & 161.3 & 1.44 & 52.2 & 0.46 & 2.5 & 3.2 \\
\hline Coastal bush & 23.3 & 0.21 & 53.6 & 0.47 & 582.2 & 5.18 & -6.5 & -46.9 \\
\hline Thickets with trees & 889.1 & 7.93 & 773.1 & 6.91 & - & - & 0.7 & 4.8 \\
\hline Forest & 855.6 & 7.63 & 644.5 & 5.76 & 635.8 & 5.65 & 1.2 & 0.06 \\
\hline Mangrove & 2072.2 & 18.48 & 1719.8 & 15.38 & 1872.9 & 16.66 & 0.9 & -0.4 \\
\hline Settlement with mixed cash crop & 2358.6 & 21.04 & 2611.1 & 23.35 & 2230.7 & 19.84 & -0.5 & 0.7 \\
\hline Residential plots & 179.3 & 1.59 & 189.8 & 1.69 & 159.5 & 1.41 & -0.3 & 0.8 \\
\hline Seasonal swamp & 1.4 & 0.01 & 1.7 & 0.01 & 2.3 & 0.02 & -1.1 & -1.7 \\
\hline Tide flats & 309.1 & 2.75 & 344.2 & 3.07 & 274.3 & 2.44 & -0.6 & 1.3 \\
\hline Mud flats & 141.6 & 1.26 & 174.7 & 1.56 & 59.1 & 0.52 & -1.2 & -3.2 \\
\hline Beach & 78.9 & 0.79 & 88.1 & 0.78 & 42.1 & 0.37 & -0.6 & 2.5 \\
\hline Water & 3759.5 & 33.54 & 3933.1 & 35.17 & 3981 & 35.43 & -0.2 & -0.01 \\
\hline Town & - & - & 239.6 & 2.14 & 252.7 & 2.24 & - & -0.3 \\
\hline Barren land & - & - & 92.7 & 0.82 & 353.1 & 3.14 & - & -13.4 \\
\hline Coastal bush with trees & - & - & - & - & 112.1 & 0.99 & - & - \\
\hline Settlement & - & - & - & - & 260.1 & 2.32 & - & - \\
\hline Hotel & - & - & - & - & 127.1 & 1.13 & - & - \\
\hline Private holiday house & - & - & - & - & 168.7 & 1.5 & - & - \\
\hline Total & $11,207.9$ & 100 & $11,181.3$ & 100 & $11,235.7$ & 100 & - & - \\
\hline
\end{tabular}

centers (239.6 ha) and barren land (92.7 ha). The 2010 land use map displays conversion of areas initially covered by thickets with trees to urban centers, barren land and coastal bushes. For example, thickets with trees which covered (773.1 ha) in 1989 was converted into other land use types such as; town, barren land, and coastal bush with a few old trees. Examples of land use types observed in 2010 were; expansion of settlements without any cash crop trees, and an increasing number of private holiday houses, and hotels.

\subsection{Land Use Change Rate}

The main land use changes between 1969 and 1989 were; decline of scrub land, miscellaneous coastal vegetation, coastal bush, thicket with trees, and mangroves (Table 2) whereas two new types of land use emerged during this period namely; town and barren land. The largest land use change rate observed between 1969 and 1989 was in miscellaneous coastal vegetation at $2.5 \%$ while coastal bush experienced the significant change rate with $-6.5 \%$. Areas covered by scrub, forest, and mangrove, experienced change rates of $1.4 \%, 1.2 \%$, and $0.9 \%$ respectively. The main land use changes observed between 1989 and 2010 were increasing coastal bush, an expansion of town and urban areas, hotels, and private holiday houses. Furthermore there was decline in miscellaneous coastal vegetation and total conversion of thickets with trees, to other land use types observed during this period. In the period between 1989 to 2010 the highest decline was observed in; coastal bush, thickets with trees and barren land, which accounted for; $-46.9 \%$ and $4.8 \%$ respectively. The area covered by barren land showed an increasing pattern from 1989-2010 with the change rates of $-13.4 \%$. 


\subsection{Main Drivers of Land Use Change and Conversion}

The results of multiple regression model showed that the major determinants of land use change were; population $(p<0.05$, actual $\mathrm{p}$-value $0.000(4.27418 \mathrm{E}-66)$, and policy $(p<0.05$, actual $p$-value $0.000(8.89021 \mathrm{E}-09)$ although rainfall was not significant $(p=0.656461979)$. The multiple regression analysis results depicted that the estimates were significant at $(p<0.05)$ as predictors of the observed changes in land use.

\subsection{Trends of the Main Drivers of Land Use Change}

Land use in Watamu Mida creek coastal area has experienced rapid change during the last 41 years (1969-2010) following the increasing tourist flows and expansion of tourist facilities and urbanization. The finding of this study revealed that, the land use cover in 1969 had very few settlements and most of the area was covered by coastal vegetation types dominated by mixed cash cropping with the main trees being ; cashew nuts, mango, and coconuts. This is the land use type classified under, settlement with mixed cash crops. In 1969 this land use type revealed a similar kind of pattern where by the land was divided between areas planted with cash crops and the rest of each plot being covered by old trees and bushes. According to the information gathered during the household survey, during the colonial administration, there were settlement schemes where each settler was given 12 acers of land with an obligation to plant cash crops, and to maintain cleared boundaries and to leave the remaining part of each plot under old trees and bushes. This information agrees with the history of settlement schemes along the Kenyan coastal area. According to Hoorweg (2000) in 1938, 850 families were settled on a 4000 ha of land near Gede. The farmers were given 12 acres (4.8 ha) of land. A recent study by Carter (2013), indicated that most of the villages were legally established after the 1950s land resettlement schemes. In his study Hoorweg (2000) stated the division of each of the12 acres of farmland as; "six acres for annual crops, three acres for perennial crops such as coconut, palms, cashew trees and fruit trees, and three acres for fodder crops, miscellaneous trees and the home compound". Respondents stated that in some villages they used to grow; maize, sesame, cottons, peas, cassava and beans. After independence the plots which used to have similar patterns in 1969 changed with new land uses including; a decline in mixed cash cropped areas, an expansion of settlement, conversion of land into towns and clearance of natural vegetation including a decline in the forest and mangrove areas. Both the 1989 and 2010 land use change map and the information obtained from the household survey showed that there was an increasing intensity of land use during this period.

A number of factors have been reported to work either individually or in concert to cause land use change and conversions. Jan (2005) attributed land use change to interaction between socioeconomic, institutional and environment factors. A study in Tanzania by Misana et al. (2012) showed that land use change was driven by a combination of different factors such as; demographic, institutional, economic, government policies, and sociocultural, technological and infrastructure. Other research in Northern Ethiopia pointed out that government policy was amongst the main socioeconomic drivers of land use change in the area (Tsegaye et al., 2010). In the current study, land use change is significantly affected by population and policy with a "p" value of $<0.000$. While assessment of respondent's opinions indicated the key drivers of change in land use were, economic $(62 \%)$ and population $(22 \%)$.

Coastal development in association with an expanding tourism industry has contributed to high demand for land to build hotels, private holiday houses, businesses and service centers. As the tourism industry expanded many people from other parts of the country have migrated in search of job opportunities to the Watamu Mida creek area. The number of hotels increased, the town expanded, areas which used to be covered by coastal bush, thickets with trees, and forest started to decline and was converted in to other land uses. Based on the census data of 1969, 1989, 1999 and 2009, the population of Watamu Mida area has grown as follows; 21,032, 50,258, 75,414 and 101,689 over the respective time period. The increasing human population has brought about land fragmentation with the original settlement schemes being sub divided and distributed to other family members including the younger generations. The result agrees with the findings of Carter (2013) that these farmlands had been divided among the sons.

Areas which were previously left to grow natural trees and bushes and grazing areas have been converted into settlements and often are also used to grow cash crop trees such as coconuts and Casuarina equisetifolia trees. Due to increasing demand of poles arising from the hotel industry, areas covered by coastal bushes and old trees has been converted to Casuarina equisetifolia, thereby replacing the old cashew nut trees. This in turn has reduced the amount of land which was under cultivation and cash crop trees between 1969 and 1989. Furthermore, 
the expansion of infrastructure further led to clearance of more areas under coastal vegetation and forest. In addition because of the growing number of tourists in the study area, the number of people migrating to Watamu in search of business and job opportunities has increased. Based on the report of Government of Kenya (2009), migration to the coastal region is due to employment opportunities, and the growth of tourism industry. The increasing number of migrants in the area has had an impact on the land use change observed on the 2010 land use map. According to Bridges et al. (2001) population growth and changes are main driving factors for the change in the natural resources base including the quality of the land itself. The influx of settlement is mainly attributed to immigration of people to Watamu area in search of business and employment opportunities. This has led to the former farmland mixed cash crop areas being converted into settlement areas in order to accommodate the increasing demand of housing for the people who came looking for jobs. As the household survey respondents confirmed, the productivity of the land has declined and farmers particularly in the vicinity of the shoreline have started selling their land to foreigners in order to raise money to support their family needs. This trend has been observed in villages such as; Watamu, Dongokundu, Blue bay, and Jacaranda. Other villages are also beginning to experience similar changes although these are not yet as extreme as the above mentioned villages.

In the Jacaranda area the land was mainly covered by coastal bush with tickets and old trees before the expansion of settlements and hotels. For example, the dominant tree types that used to cover this area were; Azadirachta indica, Afzelia quanzensis, Balanites wilsoniana, and Ficus sansiba rica. However this land cover type has been slowly cleared and the old trees cut down to use as a source of firewood and charcoal making. As respondents of the household survey and the Focused Group Discussion confirmed, the expansion of urban areas and growth in human population has led to an increased demand for firewood and charcoal. Most of the respondents agreed that there were originally lots of big trees and they started to observed significant changes occurring in the land use starting from the early 1990s. Presently some part of the area is used for coral mining because of the high demand of construction materials from nearby big tourist hotels. Several big tourist hotels and private holiday houses are being built in Jacaranda village replacing the old coastal vegetation cover.

\subsection{Impact of Land Use Change on Shoreline}

The change in land use has had an impact on shoreline changes as well. The beach front plots were private residential houses owned mainly by foreigners for a long time. The southern part of the beach front is adjoined by approximately 50 residential houses and the Marine Park. These plots were mainly covered by old trees; and coastal bushes which protected the area from erosion. Most plots in this residential area were 8 to 12 acres in size. Currently many of the plots have been converted into very big hotels and several private holiday house complexes. Some of the beach front (mainly where there are big hotels), has been leveled in order to get a better view of the sea. Areas which used to be thick coastal bush were cleared and replaced by ornamental trees or left without vegetation cover. The vegetation cover on the sandy beach acts as beach stabilizer by protecting the beach from erosion. Some beach front hotels have built sea walls in order to protect the property from erosion but this has only aggravated the erosion in other places along the beach. Richmond (1997) stated that environmental degradation such as clearance of mangrove forests for beach access, and up-rooting of near shore sea grass beds for touristic activities has become a feature of the tourism sector in most East African countries.

An impact of coastal land use change on a shoreline study in Taiwan (Lo and Gunasiri, 2014), indicated the effects of expansion of settlement and urbanization resulted in negative impact to the position of shoreline. Some villages such as Jacaranda further to the north, which used to be mainly covered by coastal bushes before the expansion of hotels is now rapidly being converted into big hotels and private houses. In this village the beach front is mainly hard coral rock with sandy beach coves. Much of the original vegetation cover has been cleared and the land close to the beach is fenced or under construction with new hotels or private houses.

\subsection{Impact of Land Use Change on Mangrove Forest}

The above mentioned land use changes have also had an impact on the mangrove forest. The mangrove forest has declined both in area and quality and this change is mainly observed in villages adjacent to the mangrove forest. As the human population number increases the demand for building materials, poles, and fire wood increases. As a result of the mangrove forest decline, a negative impact on livelihoods of the surrounding community has been observed. The total area of mangrove has shown a reduction in Kenya since 1985 (Kirui et al., 2012). A study by Kairo (2002) and Dahdouh-Guebas (2000) in Mida Creek confirmed a significant decline and 
disturbance of mangrove forest over the last 20 - 30 years mainly for poles used for house construction. In this research based on the analysis of the 2010, encroachments in to the mangrove forest have been observed. This encroachment was both by local people and foreign private holiday house owners (Figure 7). As the unpublished five year management plan prepared by (KWS, 2005) indicted, there is an indication of mangrove forest over exploitation; and decline with the number of big trees disappearing as the result of logging, settlement and selective harvesting of poles in Mida area. Even though there was a slight increment of mangrove forest area and adequate replacement rate of mangrove seedlings and saplings as observed in this study, areas adjacent to the villages were negatively affected either; by direct cutting of mangroves, (Mida, Kadaina, and Kirepwe) grazing (Mida) or encroachments (Dongokundo and Dabaso).

The impact of land use change in Watamu Mida creek area as assessed in this study revealed a decline in most coastal vegetation cover types from 1969 to 2010. These included; mangroves and conversion of land use types which were under miscellaneous coastal vegetation or coastal bush and thickets with trees to, settlement, urbanization and tourist facilities such as hotels and holiday houses. The expansion of urban areas, hotels and private holiday houses resulted in the conversion of land cover which was dominated by old trees and cash crop trees such as; coconut, palms, cashew trees, fruit trees, and fodder crops. A considerable increase in barren land, town, private holiday houses and hotels was observed between the periods 1989 to 2010. This change in land use and conversion was mainly due to an increase in human population, migration from the other part of the country in search of employment and, business opportunities and the ever increasing tourism industry in the area. Population and policy were found to be the major driving forces of changes in land use.

\section{Conclusion}

The impact of land use change in Watamu Mida creek area as assessed in this study revealed a decline in most coastal vegetation cover types from 1969 to 2010. These included mangroves and conversion of land use types which were under miscellaneous coastal vegetation or coastal bush and thickets with trees to settlement, urbanization and tourist facilities such as hotels and holiday houses. The expansion of urban areas, hotels and private holiday houses resulted in the conversion of land cover which was dominated by old trees and cash crop trees such as coconut, palms, cashew trees, fruit trees, and fodder crops. A considerable increase in barren land, town, private holiday houses and hotels was observed between the periods 1989 to 2010. This change in land use and conversion was mainly due to an increase in human population, migration from the other part of the country in search of employment and, business opportunities and the ever increasing tourism industry in the area. Population and policy were found out to be the major driving forces of changes in land use.

The impact of land use change was also observed along the coastline of Watamu. The study indicated increasing pressure from tourism related developments which harmed the general environment including marine life such as sea turtles. Some beach front hotels have leveled the beach to get a better view, and coastal vegetation has been cleared and replaced by ornamental trees or left without vegetation cover which has exposed the sandy beach to increased erosion. The land use change in Watamu Mida creek has also put pressure on the remaining mangrove forest. As settlement has expanded, villages adjacent to the mangrove forest have encroached into the mangrove reserve. Another threat to the mangroves has come from a number of holiday houses which have cleared the mangroves in order to get a better view of the sea. The increasing demand for building materials such as poles and firewood also puts a high pressure on the mangrove forest.
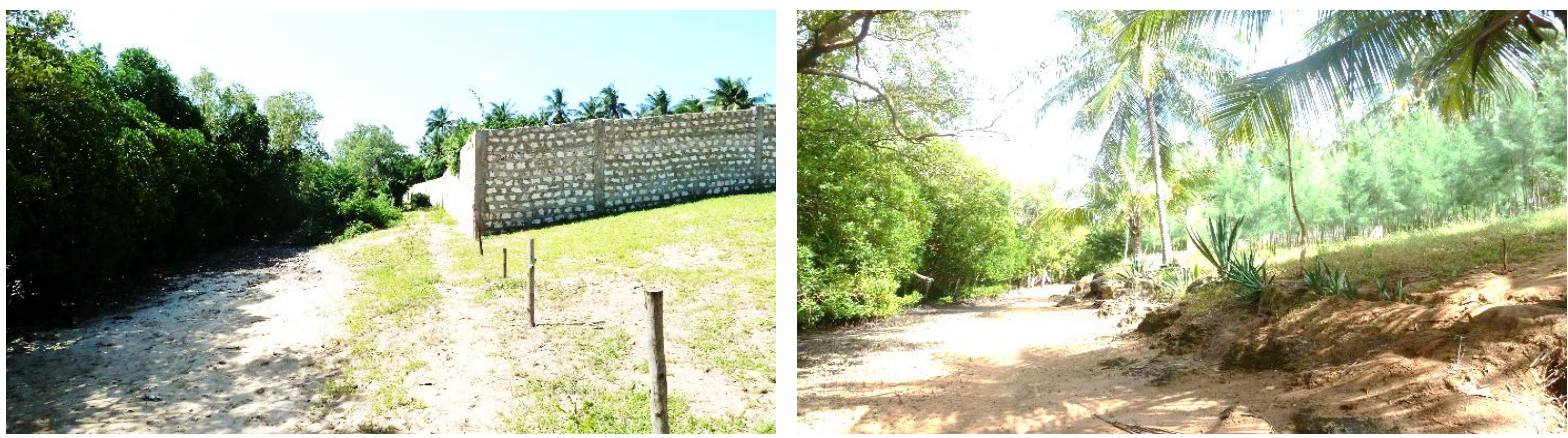

Figure 7. Private holiday house and local village encroachment to the mangrove forest. 
The mandated institutions in the area such as the Kenya Wildlife Service and Kenya Forest Service, as well as other offices, like the National Environmental Management Authority (NEMA) and the Ministries of Tourism, and Fisheries Department, have responsibilities to make sure that tourism developments are carried out without compromising the environmental, cultural values and social diversity of the area. Policies and regulations which are not currently implemented need to be updated based on the current pressure-state situation, and there should be strong law enforcement and strict regulation to control any unplanned developments along the coast and in the neighboring hinterland. This study recommends firm action needs to be taken to control unplanned and unregulated changes before it is too late.

\section{Acknowledgements}

This research is fully supported by the Regional Universities Forum for Capacity Building in Agriculture (RUF-ORUM) and the author is thankful for the support given to conduct the field work. The author would like to thank UNIDO COAST Project for the use of the 2010 Worldview satellite image and Planet Action for providing the 2002 Spot satellite image. The author also wishes to thank all the; communities, hoteliers, government officials and residents along the Watamu beach for sharing their information and Dr. Hugh Gibbon for his financial support.

\section{References}

Agarwal, C., Green, G. L., Grove, M., Evans, T., \& Schweik, C. (2000). A Review and Assessment of Land Use Change. Models Dynamics of Space, Time and Human Choice. United States Department of Agriculture Forest Service's Northern Research Station General Technical Report NE-297.

Ahmed, A. (2011). Some of the Major Environmental Problems Relating to Land Use Changes in the Coastal Areas of Bangladesh. Journal of Geography and Regional Planning, 4, 1-8.

Bridges, M. E., HannamIan, D., Oldeman, R. L., de Vries, P., Frits, W. T., Scherr, S. J., \& Sombatpanit, S. (2001). Response to Land Degradation. New Delhi: Oxford and IBH Publishing.

Central Bureau of Statistics Nairobi, Kenya (1969, 1989, 1999, 2009)

Christine Carter (2013). Tourism, Conservation and Development around a Marine Protected Area in Kenya. PhD Thesis, London: University College London, University of London.

Dahdouh-Guebas, F., Mathenge, C., \& Kairo, N. K. (2000). Utilization of Mangrove Wood Products around Mida Creek (Kenya) amongst Subsistence and Commercial Users. Economic Botany, 54, 513-527.

http://dx.doi.org/10.1007/BF02866549

Fox, J., Rindfuss, R. R., Walsh, S. J., \& Mishra, V. (2003). People and the Environment. Approaches for Linking Household and Community Surveys to Remote Sensing and GIS. Norwell, MA: Kluwer Academic Publishers.

Gang, P. O., \& Agatsiva, J. L. (1992). The Current Status of Mangroves along the Kenyan Coast: A Case Study of Mida Creek Mangroves Based on Remote Sensing. Hydrobiologia, 247, 29-36. http://dx.doi.org/10.1007/BF00008202

Government of Kenya (2009). State of the Coast Report: Towards Integrated Management of Coastal and Marine Resources in Kenya (88 p). Nairobi: National Environment Management Authority (NEMA).

Gutman et al. (2004). Chapter 26: Land Use and Land Cover Change Pathways and Impacts. Land Change Science: Observing, Monitoring, and Understanding Trajectories of Change on Earth's Surface. Netherlands: Kluwier.

Hansen, A. J., De Fries, R., \& Turner, W. (2004). Land Use Change and Biodiversity: A Synthesis of Rates and Consequences during the Period of Satellite Imagery. Pgs 277-299 Land Change Science: Observing, Monitoring, and Understanding Trajectories of Change on the Earth's Surface. New York: Springer Verlag.

Hersperger, A. M., Gennaio, M. P., Veburg, P. H., \& Burgi, M. (2010). Linking Land Change with Driving Forces and Actors: Four Conceptual Models. Ecology and Society, 15, 1.

Hoorweg, J. C. (2000). The Experience with Land Settlement. In J. C. Hoorweg, D. Foeken, \& R. Obudho (Eds.), Kenya Handbook: Culture, Resources and Development in the East African Littoral (pp. 309-326). Hamburg: LIT Verlag.

Horning, N. (2004). Justification for Using Photo Interpretation Methods to Interpret Satellite Imagery: Version 1.0 American Museum of Natural History, Center for Biodiversity and Conservation. http://biodiversityinformatics.amnh.org

Jan, P. L., Peter, H. V., \& Steven, J. S. (2005). Statistical Methods for Analyzing the Spatial Dimension of Changes in Land Use and Farming Systems. LUCC Report Series 7, International Livestock Research Institute.

Kairo, J. G., Dahdouh-Guebas, F., Gwada, P. O., Ochieng, C., \& Koedam, N. (2002). Regeneration Status of Mangrove Forests in Mida Creek, Kenya: A Compromised or Secured Future? AMBIO: A Journal of the Human Environment, 31, 562- 
568. http://dx.doi.org/10.1579/0044-7447-31.7.562

Kenya Wildlife Service (2005). Marine Protected Areas: The Five Year Management Plan in Collaboration with Key Stakeholders (1999/2000-2004/2005). (Unpublished Document)

Kirui, K. B., Kairo, J. G., Bosire, J., Viergever, K. M., Rudra, S., Huxham, M., \& Briers, R. A. (2012). Mapping of Mangrove Forest Cover Change along the Kenya Coastline Using Landsat Imagery. Ocean and Coastal Management.

Lo, K. F. A., \& Gunasiri, C. W. D. (2014). Impact of Coastal Land Use Change on Shoreline Dynamics in Yunlin County, Taiwan. Environments, 1, 124-136. http://dx.doi.org/10.3390/environments1020124

Misana, S. B., Sokoni, C., \& Mbonile, M. J. (2012). Land Use/Cover Change and Their Drivers on the Slopes of Mount Kilimanjaro, Tanzania. Journal of Geography and Regional Planning, 5, 151-164.

Munasinghe, M., \& Shearer, W. (1995). Defining and Measuring Sustainability: The Biogeochemical Foundations. Washington DC: The International Bank for Reconstruction and Development/the World Bank.

Peng, J., Wu, J., Yin, H., Li, Z., Chang, Q., \& Mu, T. (2008). Rural Land Use Change during 1986-2002 in Lijiang, China, Based on Remote Sensing and GIS Data. Sensors, 8, 8201-8223. http://dx.doi.org/10.3390/s8128201

Ricardo, G. H., Aide, T. M., Zimmerman, J. K., Thomlinson, J. R., Helmer, E., \& Zou, X. M. (2003). The Ecological Consequences of Socioeconomic and Land Use Changes in Post Agriculture Puerto Rico. BioScience, 53, 1159.

Richmond, M. D. (1997). A Guide to the Seashores of Eastern Africa and the Western Indian Ocean Islands. Sida/Department for Research Cooperation.

Roeder, A., \& Joachim, H. (2009). Recent Advances in Remote Sensing and Geo Information Processing for Land Degradation Assessment. ISBN 9780415397698, p. 418.

The National Academy of Sciences (2007). Oceans and Human Health. Washington DC: National Academies Press. http://www.nap.edu

Tsegaye, D., Moe, S. R., Vedeld, P., \& Aynekulu, E. (2010). Land Use/Cover Dynamics in Northern Afar Rangelands, Ethiopia. Agriculture, Economics and Environment, 139, 174-180.

Turner, B. L., Skole, D., Sanderson, S., Fischer, G., Fresco, L. O., \& Leemans, R. (1995). Land-Use and Land Cover Change Science Research Plan. IGBP Global Change Report No. 35/Human Dimensions Programme Report No. 7, Stockholm/ Geneva: International Geosphere-Biosphere Programme.

Weru, S. M., Wakaba, G. M., Macharia, D., Mwakau, B. K., Njue, R. M., Verheij Koyo, A. O., Muthiga, N., Kavu, B. K., Kareko, J. K., \& Litoro, M. (2000). Management Plan: Malindi Watamu Marine Parks and Reserves. Mombasa: Kenya Wildlife Services.

Wu, J. J. (2008). Land Use Changes: Social and Environmental Impacts. A Publication of the Agricultural and Applied Economics Association CHOICES, 4th Quarter, 23(4). www.choicesmagazine.org

\section{Submit or recommend next manuscript to SCIRP and we will provide best service for you:}

Accepting pre-submission inquiries through Email, Facebook, Linkedin, Twitter, etc A wide selection of journals (inclusive of 9 subjects, more than 200 journals)

Providing a 24-hour high-quality service

User-friendly online submission system

Fair and swift peer-review system

Efficient typesetting and proofreading procedure

Display of the result of downloads and visits, as well as the number of cited articles

Maximum dissemination of your research work

Submit your manuscript at: http://papersubmission.scirp.org/ 